\title{
Article \\ The Unaccompanied Child's Right to Legal Assistance and Representation in Asylum Procedures under EU Law
}

\author{
Marina Vannelli (D)
}

\section{check for}

updates

Citation: Vannelli, Marina. 2022. The Unaccompanied Child's Right to

Legal Assistance and Representation in Asylum Procedures under EU Law. Laws 11: 11. https://doi.org/ 10.3390/laws11010011

Received: 27 September 2021 Accepted: 24 December 2021 Published: 29 January 2022

Publisher's Note: MDPI stays neutral with regard to jurisdictional claims in published maps and institutional affiliations.

Copyright: (C) 2022 by the author. Licensee MDPI, Basel, Switzerland. This article is an open access article distributed under the terms and conditions of the Creative Commons Attribution (CC BY) license (https:// creativecommons.org/licenses/by/ $4.0 /)$
Department of Law, Umeå University, 90187 Umeå, Sweden; marina.vannelli@umu.se

\begin{abstract}
The independent migration of children today is a global phenomenon present in many regions worldwide, where unaccompanied minors seeking asylum do not enjoy full protection of their rights. Among their procedural safeguards, the right to legal assistance and representation is a fundamental right strictly related to the realization of other rights contained in the UN Convention on the Rights of the Child. Nevertheless, despite the fundamental role that guardians and legal advisors play in the wellbeing of unaccompanied children seeking asylum, many issues are currently affecting the exercise and implementation of this fundamental right in several European Union Member States. Therefore, the purpose of this article is to examine the content and scope of protection of this right under EU law, while highlighting the existence of possible ambiguities or gaps in current legal standards. Which EU law rules currently protect unaccompanied minors' access to legal assistance? What changes are necessary in order to strengthen that protection for unaccompanied minors seeking asylum? These are some of the questions that this paper addresses in order to critically analyze the level of protection that Europe has provided to unaccompanied children's right to legal assistance.
\end{abstract}

Keywords: human rights; child rights; asylum; unaccompanied children; international law; legal representation; guardianship; legal assistance

\section{Introduction}

Europe has received almost 1,850,000 asylum applications from children during the last decade (EUROSTAT 2021). Among children seeking asylum, the special needs for protection of unaccompanied children due to their particular situation of vulnerability have not yet been effectively assessed (European Union Agency for Fundamental Rights (FRA) 2018; UN High Commissioner for Refugees (UNHCR) 2019).

However, it is well recognized at the normative level that unaccompanied children require special assistance and protection during asylum procedures (UNHCR 1997). Among their guaranteed procedural safeguards, the right to legal representation and assistance is a fundamental right strictly related to the realization of other rights contained in the UN Convention on the Rights of the Child (CRC). In fact, guaranteed legal representation directly contributes to the legal empowerment of children and is often highlighted as a central aspect of the broader right to access to justice. ${ }^{1}$

However, despite the clear link between the right to legal representation and access to justice, a number of problems currently negatively affect legal representation of unaccompanied children within the 27 EU Member States. The kinds of legal assistance provided by States to unaccompanied children varies greatly around Europe. For instance, while some countries provide unaccompanied minors with two representatives (a legal guardian and a lawyer) throughout the asylum process, others appoint legal advisors only after the preliminary processing has taken place (Crock 2015). Recent reports have shown that in several EU Member States, legal assistance is not provided to unaccompanied children in

1 "[C]hildren are strongly in need of legal and other appropriate assistance in order to enjoy their right to access to justice and such assistance should be free of charge (or subsidized) and effective". (Liefaard 2019, p. 209). 
every stage of the asylum procedure, and, further, representation is not usually offered by legal advisors qualified and experienced in representing children (European Council on Refugees and Exiles (ECRE) 2014). Oftentimes, no specific skills and knowledge on asylum, migration law, children's rights, or psychology are required for guardians and legal counsellors (Di Stefano 2016). In addition, the excessive workload on guardians and legal representatives is a common protective issue in several States, thereby affecting the quality of unaccompanied children's representation (ECRE 2014). Accordingly, these gaps in providing adequate legal representation to unaccompanied minors naturally begs the question: What do EU rules require from States in connection to this right? This paper seeks to directly answer this question.

In order to meet this aim, I will examine the following: (i) The asylum seeker's right to legal representation under the EU Charter of Fundamental Rights; (ii) Sources of the right to free legal representation in the Common European Asylum System (CEAS); (iii) The right to legal representation and assistance in the Commission proposals to reform CEAS and the New Pact on Migration; (iv) The European Court of Human Rights and asylum seekers' legal representation; and (vi) The right to legal representation and assistance as interpreted by the Court of Justice of the European Union.

Nonetheless, before engaging in this epistemological endeavor, an analysis of the scope of "legal representation and assistance", particularly in connection to unaccompanied minors, is necessary to more fully understand current EU rules and the issues surrounding this right. After this initial step, this paper will seek to identify the extent of this right under current standards and determine the existence of possible ambiguities, gaps, or contradictions in EU law, as well as define the potential barriers to the effective protection of unaccompanied children in terms of legal representation at the European level.

\section{Legal Assistance and Representation: Two Sides of the Same Coin}

Several issues affecting the right to representation and assistance of unaccompanied children are connected to the lack of definitions surrounding this right. For instance, scholars have often questioned the scope of the right, asking: What should legal assistance and representation include? What are the differences between guardianship and representation? When should representation be appointed, and which type of representation is needed during the asylum procedure in connection to children? With these questions in mind, in order to have a comprehensive understanding of what is meant by legal representation and assistance, and in order to identify the corresponding States' obligations, it would be necessary to define and limit the scope of this right as included in European law.

However, while the right to legal representation and assistance is recognized under EU law, there are no common definitions agreed in connection to this right (FRA 2014). In addition, as the rules concerning representation and the terminology applied at the national level vary significantly, difficulties appear when one attempts to apply common terminology such as guardians, advisors, or representatives in different EU Member States.

Within EU legislation, the different roles and tasks of the personnel involved in the asylum-seeking child's representation and assistance (such as guardians, legal representatives, advisers, or counsellors) are not determined. In fact, the term "guardian" is not defined under $\mathrm{CEAS}^{2}$, and the directives only refer to "representative" or "legal representative", broadly describing a "person or an organization appointed by the competent bodies in order to assist and represent an unaccompanied minor in procedures provided for in this Directive with a view to ensuring the best interests of the child and exercising legal

2 Only used in the EU: Council of the European Union, Directive 2011/36/EU of the European Parliament and of the Council of 5 April 2011 on preventing and combatting trafficking in human beings and protecting its victims, and replacing Council Framework Decision 2002/629/JHA (Antitrafficking Directive) and the EU: Council of the European Union, Directive 2011/95/EU of the European Parliament and of the Council of 13 December 2011 on standards for the qualification of third-country nationals or stateless persons as beneficiaries of international protection, for a uniform status of refugees or for persons eligible for subsidiary protection, and for the content of the protection granted (recast), (Recast Qualification Directive). 
capacity for the minor where necessary"3. This extensive definition of representatives in the asylum acquis could refer both to guardians and legal advisors.

Nevertheless, it might be possible to find some clarification under UN rules, such as through the "UNHCR Guidelines on International Protection: Child Asylum Claims under Articles 1(A) 2 and 1(F) of the 1951 Convention and/or 1967 Protocol relating to the Status of Refugees", which clearly differentiates the roles of guardians and legal assistants. The term "guardian" is here defined as an independent person who is in charge of the child's best interest and general wellbeing, differing from legal advisors, who specifically provide legal assistance in connection only to the legal matters during legal procedures (UNHCR 2009, p. 26).

These definitions are also shared by the Fundamental Rights Agency's "Handbook on Guardianship", where explanations concerning the roles of guardians are provided. According to FRA, "guardians" exercise three distinctive functions: ensuring the child's overall wellbeing, safeguarding the child's best interests, and exercising legal representation to complement the child's limited legal capacity (FRA 2014). The roles of "legal assistants" or "advisors", on the other hand, are strictly connected to legal assistance and the legal representation of the child before legal proceedings, such as the asylum procedure (FRA 2014).

In this sense, while the child's lawyer, legal assistant, or legal advisor should be a person qualified to provide legal assistance, aid, or counselling during the asylum proceedings and to assist the child in all legal matters, the guardian or legal representative will focus on the general wellbeing of the child, including, for instance, on all matters connected to the child's health, education, and accommodation. The adequacy of representation relies precisely on the effectiveness of the interplay between guardians and legal advisors. Effective protection by a guardian and also by a lawyer is an indispensable component for the wellbeing of unaccompanied children, particularly because without legal representation, the probabilities of them presenting their claims successfully are relatively low, if not nonexistent (King 2013).

Following this line of thought, it would be possible to say that the right to legal assistance and representation comprises both the child's rights to legal aid and, separately, to guardianship during the asylum procedure. This means that every unaccompanied minor applying for asylum should be entitled to the right to protection by a guardian and a lawyer or legal assistant. Regardless of the terminology applied at the national level, the right to legal representation and assistance of the unaccompanied child in the asylum procedure requires the appointment of one or several persons who will ensure the minor's general wellbeing, protect the best interest of the child, complement the legal capacity of the child when necessary, and provide legal assistance on all legal matters connected to court or administrative procedures in which the child is involved.

Nowadays, asylum procedures in EU Member States are complex proceedings which require research, evidence, the child encountering several actors (social workers, translators, psychologists, migratory authorities, etc.), and the child participating in at least one personal interview. In this context, legal assistance and representation is a necessary component of the right to due process. Moreover, guardianship and counsel are absolutely necessary to ensure that other procedural safeguards and fundamental rights of the unaccompanied child are adequately guaranteed. Unveiling the content of this right under primary and secondary sources of EU law will be the subsequent focus of this paper.

\section{The Asylum Seeker's Right to Legal Representation under the EU Charter of Fundamental Rights}

In December 2009, the Treaty of Lisbon came into force and the Charter became legally binding on EU Member States. ${ }^{4}$ Through the amendment of Article 6 of the Treaty on

3 EU: Council of the European Union, Directive 2013/33/EU of the European Parliament and Council of 26 June 2013 laying down standards for the reception of applicants for international protection (recast), Art 2 (j).

4 For an overview of the application of the Charter before 2004, see e.g., Di Federico (2011) and Defeis (2017). 
European Union (TEU), it is now recognized that the Charter "shall have the same legal value as the Treaties". ${ }^{5}$

The Charter, which now constitutes a source of primary EU law, includes six different chapters providing a set of civil, political, social, economic, cultural, and citizenship rights. Due to the wide array of rights enshrined in this instrument, it has been claimed that "the Charter presents in sharpest relief the indivisibility of human rights" (Douglas-Scott 2011, p. 651). However, the Charter is only applicable within the field of EU law, ${ }^{6}$ and all rights can be subject to a general limitation clause under Article 52. ${ }^{7}$

Asylum seekers' right to free legal representation stems from Article 18 of the Charter, which broadly establishes the right to asylum "with due respect for the rules of the Geneva Convention of 28 July 1951 and the Protocol of 31 January 1967 relating to the status of refugees and in accordance with the Treaty on European Union and the Treaty on the Functioning of the European Union". ${ }^{8}$ The recognition of the right to asylum under the Charter requires, in consequence, procedural guarantees for the effective and adequate protection of this right. As clearly stated by Guild, "in EU law (and ECHR law) where a right exists procedural obligations regarding the protection of that right are inherent". (Guild 2015, p. 265).

Among the procedural rights included in the Charter, Article 47 establishes the right to an effective remedy and to a fair trial, expressly including legal representation. This provision states:

"Everyone shall have the possibility of being advised, defended and represented.

Legal aid shall be made available to those who lack sufficient resources in so far as such aid is necessary to ensure effective access to justice".

Accordingly, as provided in Article 47, the asylum seekers' right to legal representation will depend on the need to ensure an effective access to justice and an effective remedy. The Charter also sets forth numerous additional rights related to the adequate representation of a child. For example, the Charter establishes the principle of non-refoulement (Article 19), equality before the law (Article 20), non-discrimination principle (Article 21), and the rights of the child (Article 24). Moreover, with regards to the rights of children, the Charter enshrines the best interest principle, the right of the child to express his or her views and to have those views taken into consideration, and the rights of the child to protection and care necessary for their wellbeing. Finally, Article 21 further establishes that discrimination based on age is prohibited.

In short, under the Charter, asylum seekers' right to free legal assistance and representation will rest on the need to ensure an effective remedy and effective access to justice. In the following section, the main provisions of the asylum acquis attaining to this right would be scrutinized.

\section{Sources of the Right to Free Legal Representation in the Common European Asylum System}

The Common European Asylum System (CEAS) is a legislative framework which covers all aspects of asylum procedures, such as the rules establishing the responsible

5 Treaty of Lisbon, Article 6 (1).

6 Article 51 of the Charter reads as follows. "1. The provisions of this Charter are addressed to the institutions and bodies of the Union with due regard for the principle of subsidiarity and to the Member States only when they are implementing Union law". For an overview of the theoretical and practical problems arising from the application and interpretation of Article 51(1) of the Charter see-among others-(Hancox 2013), (Fontanelli 2014) and (Andreevska 2015).

7 Article 52 of the Charter addressing the Scope of guaranteed rights states: " 1 . Any limitation on the exercise of the rights and freedoms recognised by this Charter must be provided for by law and respect the essence of those rights and freedoms. Subject to the principle of proportionality, limitations may be made only if they are necessary and genuinely meet objectives of general interest recognised by the Union or the need to protect the rights and freedoms of others".

8 The explanations to this provision provide that: "The text of the Article has been based on TEC Article 63, now replaced by Article 78 of the Treaty on the Functioning of the European Union, which requires the Union to respect the Geneva Convention on refugees". 
Member State for examining asylum applications, and the common standards for asylum procedures, reception conditions, and the recognition of beneficiaries. All Member States are bound by these measures and shall consequently ensure that their national law is compatible with this legal framework. The interpretation of this body of law relies on both national judges and the Court of Justice of the European Union (CJEU), in that national courts must interpret EU law in many cases and, in some cases (where they are the court of last instance in a matter, for example), refer their questions on the proper interpretation of an EU legal provision to the CJEU.9

For the purpose of this paper, I will rely on those rules which contain the most relevant sources in connection to the right to legal assistance of asylum seekers and, specifically, unaccompanied children. These are the Recast Asylum Procedures Directive $(2013 / 32 / \mathrm{EU}),{ }^{10}$ the Qualification Directive Recast $(2011 / 95 / \mathrm{EU}),{ }^{11}$ the Recast Reception Conditions Directive $(2013 / 33 / \mathrm{EU}){ }^{12}$ the Antitrafficking Directive $(2011 / 36 / \mathrm{EU}),{ }^{13}$ and the Recast Dublin Regulation (604/2013) or “Dublin III"14.

As will be explained below, a common element shared by the numerous directives and regulations when it comes to unaccompanied children's representation is the fact that the different roles and tasks between guardians, legal representatives, advisers, or counsellors are not explicitly defined. Instead, this legal framework mainly refers to "representative" or "legal representative" in a broad manner, combining the roles of both guardians and advisors and only referring in a general way to their fundamental function of assisting and representing the unaccompanied child in the legal procedure without specific requisites. ${ }^{15}$

To begin with, the Recast Asylum Procedures Directive (2013/32/EU) sets the main rules concerning asylum seekers' right to legal assistance in addition to the right of the unaccompanied child to legal representation. Accordingly, the directive includes both the asylum seekers' right to legal and procedural information free of charge and the right to legal representation. However, there are significant distinctions when it comes to the extent of such rights. On the one hand, Article 19 requires States to provide applicants on request with legal information free of charge concerning the procedure in connection to the applicant's particular circumstances. In addition, States are also required to provide appeal information on request, including the reason the applicant received a negative decision at first instance and the subsequent means to challenge the decision.

Similarly, free legal representation shall be provided on request in the appeals procedure, in line with Article 20. As other scholars have suggested, it is regrettable that the directive does not strengthen standards by guaranteeing free legal aid and representation at all stages of the asylum procedure, such as during the attendance at the personal interview. See e.g., (Borland 2015, p. 38). Under current law, Member States are not restrained from applying the "merits test" to the exercise of this right in cases where the court, tribunal, or competent authority considers there to be no tangible prospect of success with the application for asylum. ${ }^{16}$ However, if the decision not to provide legal assistance is not taken by a court

9 The CJEU has jurisdiction over preliminary references from national courts. See Article 267 TFEU.

10 Council of the European Union, Directive 2013/32/EU of the European Parliament and of the Council of 26 June 2013 on common procedures for granting and withdrawing international protection (recast).

11 Council of the European Union, Directive 2011/95/EU of the European Parliament and of the Council of 13 December 2011 on standards for the qualification of third-country nationals or stateless persons as beneficiaries of international protection, for a uniform status of refugees or for persons eligible for subsidiary protection, and for the content of the protection granted (recast)

12 Council of the European Union, Directive 2013/33/EU of the European Parliament and Council of 26 June 2013 laying down standards for the reception of applicants for international protection (recast).

13 Council of the European Union, Directive 2011/36/EU of the European Parliament and of the Council of 5 April 2011 on preventing and combating trafficking in human beings and protecting its victims, and replacing Council Framework Decision 2002/629/JHA

14 Council of the European Union, Regulation (EU) No. 604/2013 of the European Parliament and of the Council of 26 June 2013 establishing the criteria and mechanisms for determining the Member State responsible for examining an application for international protection lodged in one of the Member States by a third-country national or a stateless person.

15 See e.g., Recast Reception Conditions Directive (2013/33/EU), article 2 (j).

16 Recast Asylum Procedures Directive (2013/32/EU), article 20 (3). 
or tribunal, Member States are required to ensure that the applicant has the right to an effective remedy before a court or tribunal against such decision so that the applicant's effective access to justice is not, at least in theory, hindered. ${ }^{17}$

Further limitations are also prescribed. Article 21 allows Member States not to provide legal representation to appellants who are no longer present in their territory and impose monetary or time limits on the provisions of free legal and procedural information and free representation. In addition, States may require reimbursement for costs granted if the applicant's financial situation improves or the decision to provide such costs was taken based on false information provided by the applicant. ${ }^{18}$ Lastly, applicants are entitled to consult, at their own cost, a legal adviser or other counsellor at all stages of the procedure, and providers of legal representation may include nongovernmental organizations. ${ }^{19}$

Regarding the scope of legal representation, Article 22 requires Member States to ensure that legal advisers and counsellors have access to the information in the applicant's file upon which the decision is, or will be, made. The provision contains restrictions to this right based on security reasons such as national security or the security of organizations or persons who provide the information, among others. In addition, Member States shall ensure that the legal representative is able to access closed areas in order to visit the applicant and allow the applicant to be accompanied by their legal adviser or counsellor to the personal interview. ${ }^{20}$

With regards to unaccompanied children, the guarantees of this vulnerable group are expressly included within Article 25. The Article mandates that States are required to appoint "as soon as possible" a representative that represents and assists the unaccompanied child and inform the minor immediately of the appointment of his or her representative. Notably, the requirement "as soon as possible" may lead to the denial of this right by State actors, as States may suggest different interpretations considering various excuses or circumstances to retard the appointment of representatives.

In addition, the latter provision includes some general requirements concerning both the representatives' role and the quality of representation. In this regard, the unaccompanied child's representative "shall perform his or her duties in accordance with the principle of the best interests of the child and shall have the necessary expertise to that end". ${ }^{21}$ Once again, this legal framework refers, in a broad manner, to the requirements attaining this right, which could lead to different interpretations among States affecting the quality of unaccompanied minors' assistance and representation.

Representatives or advisers shall only be changed if necessary, and States shall ensure that the representative has the opportunity to inform the child about the personal interview. $^{22}$ Further, States are required to allow the representative or legal adviser of the child to be present during the interview and ask questions or make comments. ${ }^{23}$ State authorities shall also provide both unaccompanied children and their representatives with the legal and procedural information in accordance with Article $19 .{ }^{24}$

Lastly, Member States may apply one limitation in connection to the appointment of the representative for the unaccompanied minor in accordance with Article 25 (2). Following this provision, Member States may refrain from providing a representative when the unaccompanied child will reach the age of 18 before a decision at first instance is taken.

The Qualification Directive Recast (2011/95/EU) establishes common criteria for determining eligibility for international protection, including both refugee status and subsidiary

17 (Ibid.), article 20 (3). Whether children will be able to appeal an unfavorable decision in practice is a separate question.

18 (Ibid.), article 20 (5).

(Ibid.), article 22.

(Ibid.), article 23 (2) and (3)

(Ibid.), article 25 (1) (a).

(Ibid.), article 25 (1) (b).

(Ibid.).

(Ibid.), article 25 (4). 
protection. Unaccompanied children's rights are explicitly mentioned in Article 31(1), which establishes the right of every unaccompanied child to representation "by a legal guardian or, where necessary, by an organization responsible for the care and wellbeing of minors, or by any other appropriate representation including that based on legislation or court order" as soon as possible after granting international protection. State authorities should ensure that the appointed guardian or representative fulfils the needs of the child and are equally responsible for regularly monitoring the quality and exercise of these guardianships. ${ }^{25}$ As the latter provision shows, this directive enlarges the level of protection by including monitoring duties for States and including the term guardian to in its wording. However, the specificities concerning monitoring are left to States and the criteria "as soon as possible" is still the main requisite referring to the adequate time of appointment of the guardian or representative, which, as previously mentioned above, could lead to manipulations or delays in such appointments at the national level.

The Recast Reception Conditions Directive (2013/33/EU) includes minimum standards for a full set of benefits granted to individuals who apply for asylum, while specially including a chapter concerning vulnerable persons. ${ }^{26}$ In particular, State authorities have the obligation to assure the fulfilment of the principle of the best interest of the child during the implementation of the provisions of the Directive connected to minors. ${ }^{27}$ The assessment of the best interest of the child shall consider, among others, the views of the minor in accordance with his or her age and maturity. ${ }^{28}$

Article 24 refers specifically to the rights of the unaccompanied child. With regards to legal representation, this right is contemplated with the same wording as Article 25(a) of the Recast Asylum Procedures Directive. ${ }^{29}$ The only significant change is the inclusion of regular assessments concerning the availability of the necessary means for representing the unaccompanied child. ${ }^{30}$ In addition, the latter provision further requires appropriate and constant training for all those individuals working with the child in connection to the special needs of the child. ${ }^{31}$ They are also bound by confidentiality rules in connection to any information they receive during their work. ${ }^{32}$

Further, the Antitrafficking Directive (2011/36/EU) demands particular attention from State authorities to unaccompanied children victims of trafficking, and it recognizes that these children "need specific assistance and support due to their situation of particular vulnerability". ${ }^{33}$ The rights of the unaccompanied child victim of trafficking are expressly contained in Article 16, where States are required to "take the necessary measures to ensure that, where appropriate, a guardian is appointed to unaccompanied child victims of trafficking in human beings ..." ${ }^{34}$ Moreover, when the legal representative and/or guardian are appointed, "those roles may be performed by the same person or by a legal person, an institution or an authority". ${ }^{35}$

Finally, the Recast Dublin Regulation, or "Dublin III", regulates the determination of the Member State responsibilities when examining an asylum application. Article 6 establishes the right of every unaccompanied child to a representative who assists the minor with all matters concerning the Dublin procedure. In addition, it is mentioned that the representative "shall have the qualifications and expertise to ensure that the best interests of the minor are taken into consideration" during Dublin procedures and have access "to

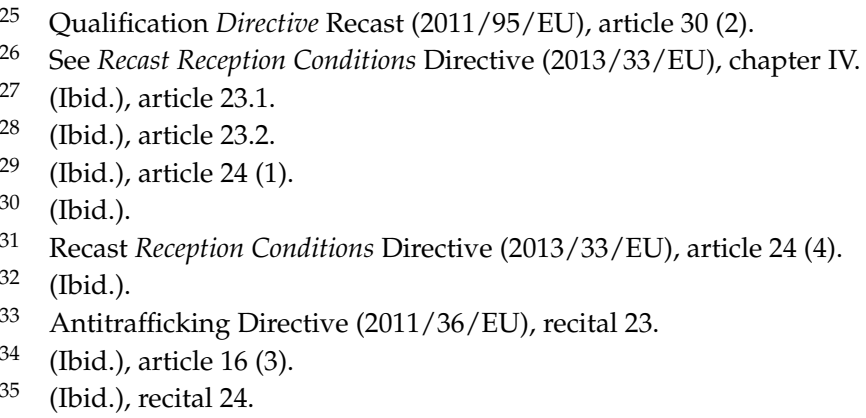


the content of the relevant documents in the applicant's file including the specific leaflet for unaccompanied minor".

Overall, it is possible to say that a number of rules concerning legal representation are established under the Common European Asylum System, but most of the standards are written in a general way, lacking clear requisites for representatives or specific obligations for State authorities. The lack of clear definitions regarding, for instance, the necessary qualifications of representatives, the differentiation between the roles of advisors and guardians and States' monitoring duties, and so on, leave a great amount of discretion for Member States at the national level. Time limits and States' obligations are also often vague, with expressions such as "where appropriate" or "as soon as possible". ${ }^{36}$

The ambiguity of legal standards at the regional level, which resultantly fails to clearly establish the content and extent of this right, is directly transposed to the national level where States offer different types of representation affecting the enjoyment of unaccompanied minors' rights and guarantees during the asylum procedure. In fact, as mentioned above, the kind of legal assistance provided by States to unaccompanied children varies around Europe. While some States offer adequate representation in terms of legal aid and guardianship from the moment the minor is identified, others include the appointment of legal advisors only once the preliminary processing takes place (Crock 2015). ${ }^{37}$ These differences and deficiencies in several protection systems at the national level appear to be tolerated under the lack of specific legal standards at the regional level.

These limitations in the framework of CEAS concerning representation, in addition to other structural issues, were exposed during the refugee crisis in $2015 .{ }^{38}$ As a consequence, the Commission proposed a structural reform of CEAS in April $2016^{39}$ and a New Pact of Migration in September 2020. ${ }^{40}$ In this regard, special attention will be given in the following section to the Commission proposals to reform CEAS in connection to the right to legal representation and assistance.

\section{The Way Forward: The Right to Legal Representation and Assistance in the Commission Proposals to Reform CEAS and the New Pact on Migration}

The Commission has enacted a wide array of proposals. The first series of proposals included reforms of the Dublin system, ${ }^{41}$ reinforcement of the Eurodac system, ${ }^{42}$ and the

36 See e.g., Antitrafficking Directive (2011/36/EU) and Recast Asylum Procedures Directive (2013/32/EU).

37 For example, in Italy and Spain, guardianship is usually entrusted to an independent body or governmental authority while in Belgium each child is appointed an individual guardian. Regarding legal counselling, in Austria, every asylum seeker has a right to free legal assistance during all the entire asylum procedure, including the admissibility stage. In Italy, on the other hand, free legal assistance of a lawyer is provided during the judicial phase of the asylum procedure as well as in administrative, civil and criminal court proceedings. For an in deep study on the differences within legal assistance systems in EU States see-among others-(ECRE 2014, 2017).

38 In the words of the Commission: "The large-scale uncontrolled arrival of migrants and asylum seekers in 2015 has put a strain not only on many Member States' asylum systems, but also on the Common European Asylum System as a whole ... The crisis has exposed weaknesses in the design and implementation of the system, and of the 'Dublin' arrangements in particular". European Commission, Towards A Reform of The Common European Asylum System And Enhancing Legal Avenues To Europe, COM (2016) 197 final, 6 April 2016, p. 3.

39 (Ibid.) See also European Commission, Communication from the Commission to the European Parliament, the Council, the European Economic and Social Committee and the Committee of the Regions. A European Agenda on Migration, Brussels, 13.5.2015, COM (2015) 240 final.

40 European Commission, Communication from the Commission to the European Parliament, the Council, the European Economic and Social Committee and the Committee of the Regions on a New Pact on Migration and Asylum, Brussels, 23.09.20, COM (2020) 609 final.

41 See European Commission, Proposal for a Regulation of the European Parliament and of the Council establishing the criteria and mechanisms for determining the Member State responsible for examining an application for international protection lodged in one of the Member States by a third- country national or a stateless person (recast), Brussels, 4 May 2016, COM (2016) 270 final.

42 See European Commission, Proposal for a Regulation of the European Parliament and of the Council on the establishment of 'Eurodac' for the comparison of fingerprints for the effective application of [Regulation (EU) No 604/2013 establishing the criteria and mechanisms for determining the Member State responsible for examining an application for international protection lodged in one of the Members States by a third-country national or a stateless person], for identifying an illegally staying third-country national or stateless person and on requests for the comparison with Eurodac data by Member States' law enforcement authorities to 
transformation of the European Asylum Support Office into a European Union Agency for Asylum with a stronger mandate, which will facilitate the functioning of the entire system. ${ }^{43}$ Further proposals included the replacement of the Qualification Directive and Asylum Procedures Directive with new regulations, ${ }^{44}$ changes to the Reception Conditions Directive, ${ }^{45}$ and the proposal establishing a Union Framework on Resettlement. ${ }^{46}$ This second set of proposals will be the subsequent focus of this section, as they include reforms to the provisions of legal representation for asylum seekers.

An important inclusion of these proposals is the replacement of the term "legal representative" for the term "guardian", 47 and the incorporation of specific provisions addressing guardians' main tasks and qualifications. Even if some aspects of guardianship continue to be established in a general manner, the standards enshrined in the proposals-as will be shown below-are certainly more extensive than the rules in the current asylum acquis.

Within the proposals, a higher level of procedural safeguards is established in connection to children and particularly to unaccompanied minors. ${ }^{48}$ With regards to legal representation, the proposal to transform the Asylum Procedures Directive into a new regulation aims to standardize guardianship practices in the Union in order to ensure that guardianship becomes prompt and effective in all EU Member States. As discussed above, standardizing guardianship practices seeks to avoid disparities within the several guardianship systems in Member States that may lead to the lack of enjoyment of unaccompanied minor's procedural guarantees, thereafter exacerbating their inadequate care or their exposure to situations that could possibly lead them to escape. ${ }^{49}$

Accordingly, the former proposal establishes that unaccompanied children should be appointed a guardian as soon as possible and no later than five working days from the moment they present an application. ${ }^{50}$ The five days limit introduces a positive modification to the Asylum Procedures Directive, as the current standard is "as soon as possible", which-as described earlier-could lead to misleading and inconsistent results among Member States. ${ }^{51}$

Europol for law enforcement purposes (recast), Brussels, 4.5.2016 COM (2016) 272. Eurodac is a large-scale IT system used by 32 States: 28 EU Member States and 4 Associated Countries (Iceland, Norway, Switzerland and Liechtenstein) to store new fingerprints and compare existing records on asylum seekers. Eurodac contributes to the management of European asylum applications by storing and processing the digitalised fingerprints of asylum seekers and irregular migrants who have entered a European country.

43 European Commission, Proposal for a Regulation of the European Parliament and of the Council on the European Agency for Asylum and repealing Regulation (EU) No 439/2010, Brussels, 4.5.2016 COM (2016) 271 final.

44 European Commission, Proposal for a Regulation of the European Parliament and of the Council on standards for the qualification of third-country nationals or stateless persons as beneficiaries of international protection, for a uniform status for refugees or for persons eligible for subsidiary protection and for the content of the protection granted and amending Council Directive 2003/109/EC of 25 November 2003 concerning the status of third-country nationals who are long-term residents, Brussels, 13.7.2016 COM (2016) 466 final and European Commission, Proposal for a Regulation of the European Parliament and of the Council establishing a common procedure for international protection in the Union and repealing Directive 2013/32/EU, Brussels, 13.7.2016 COM (2016) 467 final.

45 European Commission, Proposal for a Directive of the European Parliament and of the Council laying down standards for the reception of applicants for international protection (recast) Brussels, 13.7.2016 COM (2016) 465 final.

46 European Commission, Proposal for a Regulation of the European Parliament and of the Council establishing a Union Resettlement Framework and amending Regulation (EU) No 516/2014, Brussels, 13.7.2016 COM (2016) 468 final

47 The guardian is defined as "a person or organization appointed by the competent bodies in order to assist and represent an unaccompanied minors in procedures provided for in this Regulation with a view to ensuring the best interests of the child and exercising legal capacity for the minor where necessary". See COM (2016) 466 final, supra note 44, Article 2 (19). See also COM (2016) 465 final, supra note 45, article 2 (12) and COM (2016) 467 final, supra note 44 , article $4(2)(\mathrm{f})$

48 See COM (2016) 467 final, supra note 44, Articles 19 (applicants in need of special procedural guarantees), 21 (guarantees for minors) and 22 (special guarantees for unaccompanied minors).

49 COM (2016) 467 final, supra note 44, p. 15.

50 (Ibid.), article 22 (1). Also, COM (2016) 465 final, supra note 45, article 23 (1).

51 However, in 2018, the Council and the Parliament reached a provisional agreement on the proposal where the time limit for designation of the guardian extends to 15 days, and exceptionally to 25 working days. See Council 
The functions of the guardian are also described in Article 22 (3), which states that:

"The guardian shall, with a view to safeguarding the best interests of the child and the general well-being of the unaccompanied minor: (a) represent and assist the unaccompanied minor during the procedures provided for in this Regulation and (b) enable the unaccompanied minor to benefit from the rights and comply with the obligations under this Regulation".

In addition, Article 22 (4) reads as follows:

"The guardian shall perform his or her duties in accordance with the principle of the best interests of the child, shall have the necessary expertise, and shall not have a verified record of child-related crimes or offences".

Within the guardians' tasks, the proposal also includes that guardians are in charge of informing the unaccompanied child about the personal interview, its meaning, possible consequences, and, where appropriate, how to prepare himself or herself for such an interview. ${ }^{52}$ Guardians shall be present in the personal interview, as well as legal advisors or counsellors admitted under national law, and shall be able to ask questions and make comments. ${ }^{53}$

Moreover, State authorities are equally responsible for monitoring the quality and exercise of these guardianships, and they are required to appoint entities or persons accountable for the performance of guardians' tasks. ${ }^{54}$ Unaccompanied minors shall be entitled to lodge complaints against their guardians, ${ }^{55}$ and guardians shall be changed when responsible authorities consider that she or he does not adequately perform their main tasks. ${ }^{56}$ State authorities are also responsible for not appointing a guardian with a disproportionate number of unaccompanied children at the same time. ${ }^{57}$

Overall, the proposals provide a relevant improvement in the current legal framework concerning unaccompanied children's representation in asylum in EU Member States. The inclusion of time restrictions, monitoring systems, and clearer definitions for guardians' roles will lead to a lesser level of discretion in the implementation of this right and a better understanding of legal representation within EU States. In addition, the proposal to transform the Qualification Directive and Asylum Procedures Directive into new regulations will lead to the harmonization of standards, as regulations are directly applicable in the Member States.

Nevertheless, a few words should be said regarding the state of the proposals in the legislative process. The proposal to reform CEAS have not been formally adopted under the 2014-2019 parliamentary term, due mainly to disagreements between the Council and Parliament. ${ }^{58}$ However, the stagnation of the past years seemed to have been overcome in September 2020 when the Commission presented a new pact on migration and asylum where it supported the provisional political agreement achieved in connection to the previous proposals and urged for adoption "as soon as possible". ${ }^{59}$ However, this seems unlikely

of the European Union, Directive 2013/33/EU of the European Parliament and of the Council of 26 June 2013 laying down standards for the reception of applicants for international protection (recast) - Conditional confirmation of the final compromise text with a view to agreement, Interinstitutional File: 2016/0222 (COD), Brussels, 18 June 2018 (OR. en) 10009/18.

52 COM (2016) 467 final, supra note 44, Article 22 (6).

53 (Ibid.).

54 (Ibid.), Article 22 (5). Also, COM (2016) 465 final, supra note 45, article 23 (1).

55 COM (2016) 467 final, supra note 44, Article 22 (5).

56 (Ibid.), article 22 (4)

57 (Ibid.), Article 22 (5). Also, COM (2016) 465 final, supra note 45, article 23 (1). In the compromise text of the Council of the EU and the European Parliament a maximum number of 30 (exceptionally 50) is set. See supra note 51 .

58 See https://www.consilium.europa.eu/en/policies/ceas-reform/ceas-reform-timeline/ (accessed on 1 November 2021).

59 COM (2020) 609 final, supra note 40. 
to happen at present as the pact holds an integrated and comprehensive approach, covering all aspects of asylum and migration governance, which complicates the negotiations.

The new pact builds from and maintains the proposals while introducing additional elements to them as well. It aims to conclude the negotiations on the 2016 proposals while including several positive novelties. For instance, the pact includes the creation of integrated procedures at the borders through pre-entry screening and specific monitoring safeguards. It also calls for improvements in cooperation in the area of migration management and establishes a more effective solidarity mechanism, such as strengthening return solidarity measures.

The needs of the migrant child are identified in the pact as a priority while seeking to strengthen the safeguards of children under EU law in the context of migration. In this sense, the new proposed rules seek to ensure that all decisions concerning asylum-seeking children are taken with primary consideration of the best interest of the child and with due respect to the right of the child to be heard. Moreover, when it comes to the rights of unaccompanied children, special attention is given to this vulnerable group through, for instance, reinforcements in the right to family reunification and prioritization for relocation of unaccompanied minors. ${ }^{60}$

With regards to legal representation, the pact establishes that unaccompanied minors should be appointed a representative no later than fifteen days after an asylum application is presented. ${ }^{61}$ In addition, the role of the European Network on Guardianship ${ }^{62}$ should be strengthened while promoting stronger coordination, cooperation, and capacity- building of guardians throughout the European Union. ${ }^{63}$ The particular needs of unaccompanied children and child-specific procedural guarantees, such as ensuring the right of the child to be heard, swift family reunification, and legal assistance, throughout the entire asylum procedure should be effectively provided. ${ }^{64}$

Despite the positive aspects introduced in the pact, the legislative proposals are still being negotiated between the European Parliament and the Council of the EU. In addition, the existing tensions between Mediterranean States and Northern States based on the differences in their interests concerning secondary movements, reception conditions, accommodation, and solidarity and responsibility sharing, sets important challenges to discussions and makes it difficult to reach consensus.

Bearing these considerations in mind, in the following sections it will be critically analyzed the manner in which the European Court of Human Rights and the European Court of Justice have referred to this right in concrete cases.

\section{The European Court of Human Rights and Asylum Seekers' Legal Representation}

The European Court of Human Rights (ECtHR) ensures the correct application of the European Convention for the protection of Human Rights and Fundamental Freedoms (ECHR). Procedural guarantees in the European Convention are enshrined in Articles 6 (right to a fair trial) and Article 13 (right to an effective remedy). While these provisions are closely related, the content and extent of the rights enshrined therein are not the same. See e.g., (Borland 2015, p. 52). Article 13 ECHR can only be engaged if the applicant holds an arguable claim in connection to other provisions of the ECHR, such as, for instance, Articles

60 (Ibid.).

61 Commission staff working document Accompanying the document Proposal for a Regulation of the European Parliament and of the Council on asylum and migration management and amending Council Directive (EC)2003/109 and the proposed Regulation (EU)XXX/XXX [Asylum and Migration Fund], SWD/2020/207 final, p. 66.

62 The European Network on Guardianship seeks to improve services for unaccompanied minors within EU Members States through guardianship development and assistance to practitioners and organizations.

63 COM (2020) 609 final, supra note 40, para. 2.4 .

64 (Ibid.). 
2 (right to life), 3 (prohibition of torture), or 8 (right to respect for private life) ECHR. ${ }^{65} \mathrm{On}$ the other hand, Article 6 ECHR provides for the right to a fair hearing and access to justice in civil and criminal procedures. Further, under paragraph $3 c$, the provision recognizes the right to free legal aid in criminal proceedings under certain circumstances. ${ }^{66}$

The Court has developed an extensive jurisprudence in connection to the content and extent of States' obligations under Article 6 ECHR with regards to the granting of legal aid. ${ }^{67}$ However, in the context of migration, the regional tribunal has so far refused to accept that the procedural rights enshrined under Article 6 ECHR are applicable to asylum procedures. ${ }^{68}$ Since its first judgment regarding the applicability of Article 6(1) to expulsion proceedings of aliens in the case of Maaouia $v$. France, ${ }^{69}$ the regional tribunal has claimed that:

"[D]ecisions regarding the entry, stay and deportation of aliens do not concern the determination of an applicant's civil rights or obligations or of a criminal charge against him, within the meaning of Article $6 \S 1$ of the Convention". ${ }^{70}$

Notwithstanding the negative position of the regional tribunal regarding the applicability of Article 6 ECHR in immigration and asylum procedures, the ECtHR has recognized specific procedural guarantees to asylum seekers and migrants by the joint application of other interconnected and interrelated provisions-such as Articles 8 and 13 ECHR-to asylum procedures. ${ }^{71}$

To state it differently, while the Court has held that the procedural safeguards enshrined in Article 6 ECHR are not applicable in asylum procedures, Article 13 ECHR, which ensures the right to an effective remedy, is fully applicable in connection to asylum in cases when the applicant builds an "arguable claim" under any other provision of the Convention. ${ }^{72}$ In this sense, the Court has acknowledged on several occasions, while analyzing violations in connection to Articles 2, 3, and 8 ECHR in the context of migration, that procedural obstacles such as the lack of legal representation could result in a violation of Article 13 ECHR. ${ }^{73}$

For instance, in the case of Abdolkhani and Kariminia v. Turkey, ${ }^{74}$ the Court found that the applicants in an asylum case were not guaranteed an effective and accessible remedy in connection with their complaints based on Article 3 of the Convention. ${ }^{75}$ Thus, the Court identified a violation of Article 13 ECHR based partly on the lack of legal assistance of the applicants during detention. ${ }^{76}$ In fact, according to the regional tribunal:

"A remedy must be effective in practice as well as in law in order to fulfil the requirements of Article 13 of the Convention. In the present case, by failing to

65 See-among others-M.S.S. v. Belgium and Greece, Judgment of 21 January 2011, ECtHR, Application No. 30696/09, para. 288 and Abdolkhani and Kariminia v. Turkey, Judgment of 22 September 2009, ECtHR, Application no. 30471/09, para. 107

66 Article 6(3) ECHR reads as follows: "Everyone charged with a criminal offence has the following minimum rights: ... (c) to defend himself in person or through legal assistance of his own choosing or, if he has not sufficient means to pay for legal assistance, to be given it free when the interests of justice so require".

67 See e.g., Airey v. Ireland, Judgment of 9 October 1979, ECtHR, Application no. 6289/73; Gnahoré v. France, Judgment of 19 September 2000, ECtHR, Application no. 40031/98; McVicar v. The United Kingdom, Judgment of 7 May 2002, ECtHR, Application no. 46311/99; Steel and Morris v. the United Kingdom, Judgment of 15 February 2005, ECtHR, Application no. 68416/01.

68 See for further readings on this matter: (Guild 2015, pp. 279-80).

69 Maaouia v. France, Judgment of 5 October 2000, ECtHR, Application No. 39652/98.

70 (Ibid.), para. 40.

71 As claimed by Kilkelly: "[A]n implicit part of certain substantive provisions permits the development of safeguards which are specific to the rights guaranteed and go beyond the scope of protection of the fair trial provision (Kilkelly 1999).

72 MSS v. Belgium and Greece, supra note 65, para. 288.

73 (Ibid.) See also Čonka v. Belgium, Judgment of 5 February 2002, ECtHR, Application No. 51564/99, para. 79.

74 Abdolkhani and Karimnia v. Turkey, Judgment of 22 September 2009, ECtHR, Application No. 30471/08.

75 (Ibid.), para. 117.

76 As mentioned by the Court: "the applicants were not given access to legal assistance when they were arrested and charged, despite the fact that they explicitly requested a lawyer". Abdolkhani and Karimnia v. Turkey, supra note 74 , para. 114 . 
consider the applicants' requests for temporary asylum, to notify them of the reasons for not taking their asylum requests into consideration and to authorise them to have access to legal assistance while in Hasköy police headquarters, the national authorities prevented the applicants from raising their allegations under Article 3 within the framework of the temporary asylum procedure" ${ }^{\prime 7}$

As an additional development of this jurisprudential approach, in the case of MSS $v$. Belgium and Greece, ${ }^{78}$ the Court assessed Article 13 ECHR in connection to Articles 2 and 3 ECHR. Accordingly, the regional tribunal highlighted in this decision that the access to asylum proceedings and the examination of applications for asylum in Greece presented several deficiencies. Among these, the Court specifically highlighted "the lack of legal aid effectively depriving the asylum seeker of legal counsel"79 in addition to serious lack of information and communication issues affecting asylum seekers, ${ }^{80}$ and the lack of practical means of the applicant to pay a lawyer. ${ }^{81}$

The importance to guarantee an effective remedy in the context of migration processes where the applicant's complaint is connected to Article 3 of the Convention were further developed by the Court in the latter case of Hirsi Jamaa and Others v. Italy. ${ }^{82}$ In particular, the Court was able to recognize that the applicants had no access to a procedure that identified and assessed their personal circumstances before they returned to Libya. ${ }^{83}$ Moreover, the Court specially highlighted that " $\mathrm{t}]$ here were neither interpreters nor legal advisers among the personnel on board". 84

Further, when examining States' obligations towards children involved within migration procedures, the European Court has highlighted on numerous occasions how important is to pay attention to their special situation of vulnerability as both minors and migrants. In fact, the Court has reinforced the protection of children's rights by reaffirming that:

“This requirement of 'special protection' of asylum seekers is particularly important when the persons concerned are children, in view of their specific needs and their extreme vulnerability" ${ }^{85}$

This jurisprudence has been further consolidated with the acknowledgment of the need to introduce a differential treatment able to provide an enhanced level of protection to migrant children. In fact, the Court has repeatedly referred to several provisions of CRC that should be taken into consideration as reference points for States authorities when ensuring the effective realization of children's rights. Among these provisions, the Court has highlighted the special relevance of Article 3 (best interest of the child), 22 (appropriate protection and humanitarian assistance for refugee children), and 37 (detention and punishment). ${ }^{86}$

Accordingly, by means of reading the ECHR in the light of the CRC, the Court has acknowledged the relevance of the best interest of the child in all decisions concerning children, ${ }^{87}$ and the need to adapt the reception conditions for asylum-seeking children

\footnotetext{
(Ibid.), para. 115. (emphasis added).

M.S.S. v. Belgium and Greece, Judgment of 21 January 2011, ECtHR, Application No. 30696/09.

(Ibid.), para. 301

(Ibid.), para. 311

81 As mentioned by the Court: "although the applicant clearly lacks the wherewithal to pay a lawyer, he has received no information concerning access to organisations which offer legal advice and guidance. Added to that is the shortage of lawyers on the list drawn up for the legal aid system, which renders the system ineffective in practice". (Ibid.), para. 319.

82 Hirsi Jamaa and Others v. Italy, Judgment of 23 February 2012, ECtHR, Application No. 27765/09.

83 (Ibid.), para. 202.

84 (Ibid.) (emphasis added).

85 Tarakhel v. Switzerland, Judgment of 4 November 2014, ECtHR, Application no. 29217/12, para. 119.

86 See Muskhadzhiyeva and Others v. Belgium, Judgment of 19 January 2010, ECtHR, Application no. 41442/07, para. 62 and Popov v. France, Judgment of 19 January 2012, ECtHR, Applications nos. 39472/07 and 39474/07, para. 91. See also: (Ippolito and Iglesias 2015, p. 252).

87 Popov v. France, supra note 86, para. 140.
} 
in accordance with the child's age. ${ }^{88}$ In addition, the regional tribunal highlighted that the Convention on the Rights of the Child requires States to adopt appropriate measures that ensure that asylum-seeking children enjoy protection and humanitarian assistance regardless of the condition of the child as accompanied, separated, or unaccompanied. ${ }^{89}$ In particular, the Court has found in this context that children who apply for asylum alone can face increased levels of vulnerability. ${ }^{90}$

The jurisprudential developments of the ECtHR clearly show that the specific vulnerability connected to the condition of being a child seeking asylum justifies an increased level of protection, together with the identification of tightness obligations over State authorities. ${ }^{91}$ This rule is fully applicable to the case of unaccompanied children where their intrinsic vulnerability requires higher levels of protection from States, such as adequate legal representation and guardianship.

In fact, the court placed special focus on the extreme situation of vulnerability that affects the child who is unaccompanied in the case of Mubilanzila. ${ }^{92}$ In its reasoning, the regional tribunal condemned the two-month detention of an unaccompanied child in a center designed for adults without any person being assigned to look after her, and highlighted that the State authorities had not taken appropriate measures for her protection, as, for instance, "[N]o measures were taken to ensure that she received proper counselling and educational assistance from qualified personnel specially mandated for that purpose ${ }^{\prime \prime}{ }^{93}$

Lastly, it would be important to note that even if the Court has expressly denied the application of Article 6 ECHR and the recognition of the entitlement of the right to legal representation under this provision in asylum procedures, it has, however, also identified on several occasions the lack of representation as a predominant factor while examining asylum seekers' right to a fair remedy. In fact, by taking into consideration Article 13 ECHR in connection with other provisions of the European Convention, such as, for instance, Article 3 ECHR, the regional tribunal has required States to establish asylum procedures which contain a set of minimum safeguards, including the right to be heard. ${ }^{94}$ As evidenced under the decisions examined above, there is clear concern from the European Court regarding the need for free legal assistance during asylum procedures, especially as asylum seekers are in a special situation of vulnerability. See e.g., (Guild 2015, p. 280). This interpretative rule is clearly applicable to the case of unaccompanied children, whose specific condition of vulnerability require, from State authorities, higher levels of protection through additional safeguards. Bearing these considerations, the Court has developed an important case law aimed at strengthening the conventional protection of the rights of the migrant child.

\section{The Court of Justice of the European Union and the Right to Legal Representation and Assistance}

The judicial authority of the EU has, as its main function, to ensure the uniform interpretation and application of European Union law. ${ }^{95}$ When it comes to asylum law, the Court of Justice has examined cases concerning different aspects of migration, see (Costello

88 Tarakhel v. Switzerland, supra note 85, para. 119.

89 (Ibid.), para. 99. See also Popov v. France, supra note 86, para. 91.

90 Rahimi v. Greece, Judgment of 5 July 2011, ECtHR, Application No. 8687/08, para. 86.

91 Muskhadzhiyeva and Others v. Belgium, supra note 86, para. 53.

92 In the words of the Court: "The second applicant's position was characterised by her very young age, the fact that she was an illegal immigrant in a foreign land and the fact that she was unaccompanied by her family from whom she had become separated so that she was effectively left to her own devices. She was thus in an extremely vulnerable situation. In view of the absolute nature of the protection afforded by Article 3 of the Convention, it is important to bear in mind that this is the decisive factor (...). She therefore indisputably came within the class of highly vulnerable members of society". (Ibid.), para. 55.

93 (Ibid.), para. 50. Emphasis added.

94 See for an in deep study on this matter: (Smyth 2018, p. 141).

95 TEU Article 19 (1): “The Court of Justice of the European Union shall include the Court of Justice, the General Court and specialised courts. It shall ensure that in the interpretation and application of the Treaties the law is observed". 
2012) and (Garlick 2015). such as the minimum standards for determining who qualifies as a refugee under EU law, ${ }^{96}$ states' obligations under Dublin Regulation, ${ }^{97}$ minimum standards for the reception of asylum seekers in EU Member States, ${ }^{98}$ and asylum seekers' procedural rights. ${ }^{99}$ As indicated by the constant jurisprudence of the CJEU, it is important to highlight that States Members are under the general obligation to ensure judicial protection of an individual's rights under EU law. ${ }^{100}$

The Court of Justice has addressed the relevance of the right to legal assistance in connection to Article 47 of the Charter in the case of D.E.B., ${ }^{101}$ specifically in the context of the Council Directive 2002/8/EC of 27 January 2003 to improve access to justice in crossborder disputes by establishing minimum common rules relating to legal aid for such disputes. The latter directive applies to Union citizens and third-country nationals domiciled or who are habitual residents in a Member State in connection to cross-border disputes and to civil and commercial matters, whatever the nature of the court or tribunal. ${ }^{102}$ Hence, it leaves outside the scope of its application legal aid in asylum procedures. However, it is worth focusing on this decision, as the reasoning of the Court in the case of D.E.B could be translated to cases concerning asylum seekers and their right to effective remedy. ${ }^{103}$

In this case, the Court of Justice examined the scope of Article 47 of the Charter with regards to legal aid by interpreting the provision in its context, i.e., in connection to "other provisions of EU law, the law of the Member States and the case-law of the European Court of Human Rights". ${ }^{104}$ As a result of this integrative approach, the court recognized that the grant of legal aid in connection to the right to an effective remedy shall be made "on the basis of the right of the actual person whose rights and freedoms as guaranteed by EU law have been violated". 105

Moreover, the regional tribunal specifically recognized that the principle of effective judicial protection should be interpreted as including legal aid related to the payment of the costs of the procedures and/or the assistance of a lawyer. ${ }^{106}$ Lastly, national courts should assess whether the conditions for granting legal aid constitute a limitation to the right to access to courts which undermines the core of the right, pursuing a legitimate aim and whether there is a reasonable relationship of proportionality between the means employed and the legitimate aim which is sought to achieve. ${ }^{107}$ When making the latter assessment, national court shall take into consideration:

"The subject-matter of the litigation; whether the applicant has a reasonable prospect of success; the importance of what is at stake for the applicant in the proceedings; the complexity of the applicable law and procedure; and the applicant's capacity to represent himself effectively. In order to assess the proportionality, the national court may also take account of the amount of the costs of the proceedings in respect of which advance payment must be made and whether or not those costs might represent an insurmountable obstacle to access to the courts". ${ }^{108}$

96 E.g., Joined cases C-57/09 and C-101/09, Bundesrepublik Deutschland v. B and D, CJEU, 9 November 2010; joined cases C-7/11 and C-99/11, Bundesrepublik Deutschland v. Y and Z, CJEU, 5 September 2012 and joined cases C-199/12, C-200/12 and C-201/12, X, Y and Z, CJEU, 7 November 2013.

97 E.g., Joined cases C-411/10 and C-439/10, N.S v. United Kingdom and M.E. v. Ireland, CJEU, 21 December 2011.

98 Case C-179/11, Cimade Gisti v. Ministre de l'Intérieur de l' Outremer, des Collectivités territoriales et de l'Immigration, CJEU, 27 September 2012.

99 Case C-69/10, Brahim Samba Diouf v Ministre du Travail, de l'Emploi et de l'Immigration, CJEU, 28 July 2011.

100 See Case C-63/08, Virginie Pontin v. T-Camalux SA, CJEU, 29 October 2009, para. 44.

101 Case C-279/09 DEB Deutsche Energiehandels-und Beratungsgesellschaft mbH v. Bundesrepublik Deutschland (2010) ECR I-13849, CJEU, 22 December 2010.

102 See Council Directive 2002/8/EC of 27 January 2003 to improve access to justice in cross-border disputes by establishing minimum common rules relating to legal aid for such disputes, articles 1-3.

103 See e.g., (Guild 2015, pp. 281-84).

104 Case of D.E.B, supra note 101, para. 37

105 (Ibid.), para. 42.

106 (Ibid.), para. 59.

107 (Ibid.), para. 60.

108 (Ibid.), para. 61. 
Accordingly, the application of this decision in the context of asylum could lead us to conclude that States need to follow the criteria established above in each particular asylum case in connection to the provision of legal assistance. In addition, the asylum seekers' right to legal aid, established in CEAS, should not be interpreted in isolation, but taking into consideration the context of the legal system of reference, including other instruments and agreements directly related to EU asylum law. Under this integrative approach, the interpretation of asylum seekers' right to legal assistance should also consider-as elaborated by the European Court in the D.E.B. case-the jurisprudence of the ECtHR in connection to the right to legal aid and Article 47 of the Charter.

Further clarifications connected to the right to legal aid were developed by the regional tribunal in connection to vulnerable persons. For instance, in Pontin, the Court held that time limits in the procedure could make it too difficult for the applicant to obtain legal advice, due to the applicant's special condition of vulnerability, such as in the situation of a dismissed pregnant women. ${ }^{109}$ Accordingly, a 15-day period as time limit for bringing an action for nullity and reinstatement could be reasonable in other cases, but, combined with the vulnerability position of certain applicants, could result in a violation of the applicant's procedural rights. This rule is fully applicable in connection to asylum seekers.

Lastly, the regional tribunal has recently ruled a remarkable judgment in the case of $T Q v$. Staatssecretariis van Justitie en Veiligheid ${ }^{110}$ regarding the interpretation of several provisions of the Return Directive $(2008 / 115 / E C)^{111}$ in cases involving unaccompanied minors whose application for international protection has been rejected. In this case, the court identified States' obligation "to apply the best interests principle at all stages of the procedure"112 before taking any return decision. In addition, the regional tribunal emphasized how important is to hear the unaccompanied child before adopting a return decision with regards to the conditions in which she or he might be received in the State of return. ${ }^{113}$ This rule is clearly connected to the right to legal assistance and representation of the unaccompanied child, as the adequate exercise of this right is absolutely necessary to hearing the child properly and examining their best interest in each particular case.

\section{Conclusions}

This paper has thoroughly examined the main legal developments at the EU level concerning legal representation and assistance for unaccompanied children seeking asylum in the EU. In addition, several deficiencies in current EU rules concerning this right, which lead to significant challenges and disparities in its implementation at the national level, have been highlighted. Among these, one can mention the overbroad and vague definition of the term "representatives" in the asylum acquis-which could refer both to guardians and legal advisors-and the lack of specific standards for legal representation and assistance in the case of unaccompanied minors. In fact, the lack of clarification in the asylum acquis reflects a lack of consistency and harmonization among Member States in the application of EU law when it comes to unaccompanied children's representation.

The continuous sufferings of this vulnerable group confirm that the current general standards of protection have not been enough, and that legal certainty needs to be achieved if the present ambiguities and gaps in the protection of unaccompanied children are to be solved. As both CJEU and ECtHR have recognized, the right to legal representation is strictly connected to the right to justice, a fundamental human right interrelated with other rights enshrined in the CRC and the EU Charter. The right of the unaccompanied minor to legal representation and assistance is necessary to ensure the effectiveness of other

109 Case C-63/08, Virginie Pontin v. T-Camalux SA, CJEU, 29 October 2009, para. 65.

110 Case C-441/19, TQv Staatssecretariis van Justitie en Veiligheid, CJEU, 14 January 2021.

111 Council of the European Union, Directive 2008/115/EC of the European Parliament and Council of 16 December 2008 on common standards and procedures in Member States for returning illegally staying third-country nationals.

112 Case C-441/19, TQ v Staatssecretariis van Justitie en Veiligheid, supra note 110, para. 44.

113 (Ibid.), para. 59. 
procedural guarantees. In fact, proper representation constitutes an effective mechanism to avoid unfounded deportations that could result in violations of other rights, such as the best interest principle and the right to family reunification. As such, ensuring unaccompanied minors protections both procedurally and substantively is of resolute importance.

Funding: This research received no external funding. The arguments in this article are drawn in part from the author's unpublished PhD thesis. The PhD is funded by Umeå University.

Institutional Review Board Statement: Not applicable.

Informed Consent Statement: Not applicable.

Data Availability Statement: Not applicable.

Conflicts of Interest: The author declares no conflict of interest.

$\begin{array}{ll}\text { Abbreviations } \\ \text { CEAS } & \text { Common European Asylum System } \\ \text { CJEU } & \text { Court of Justice of the European Union } \\ \text { CRC } & \text { UN Convention on the Rights of the Child } \\ \text { ECRE } & \text { European Council on Refugees and Exiles } \\ \text { ECHR } & \text { European Convention on Human Rights } \\ \text { ECtHR } & \text { European Court of Human Rights } \\ \text { EU } & \text { European Union } \\ \text { EUROSTAT } & \text { European Statistics } \\ \text { FRA } & \text { European Union Agency for Fundamental Rights } \\ \text { TEU } & \text { Treaty on European Union } \\ \text { TFEU } & \text { Treaty on the Functioning of the European Union } \\ \text { UNHCR } & \text { UN High Commissioner for Refugees }\end{array}$

\section{References}

Andreevska, Elena. 2015. The Applicability of the EU Charter of Fundamental Rights: National Measures. Challenge of the Knowledge Society 5: 349-56.

Borland, Emma. 2015. Fair enough? The UK's Reluctance to Find Article 6 ECHR Engaged in Asylum Disputes and the Transformative Potential of EU law. In Seeking Asylum in the European Union: Selected Protection Issues Raised by the Second Phase of the Common Asylum System. Edited by Céline Bauloz, Meltem Ineli-Ciger, Sarah Singer and Vladislava Stoyanova. Leiden and Boston: Brill Nijhoff, pp. 23-57. ISBN 978-90-04-29016-7.

Costello, Cathryn. 2012. Courting Access to Asylum in Europe: Recent Supranational Jurisprudence Explored. Human Rights Law Review 12: 287-339. [CrossRef]

Crock, Mary E. 2015. Justice for the Migrant Child: The Protective Force of the Convention on the Rights of the Child. In Child-Friendly Justice. A Quarter of a Century of the UN Convention on the Rights of the Child. Stockholm's Studies in Child Law and Children's Rights. Edited by Mahmoudi Said, Pernilla Leviner, Anna Kaldal and Katrin Lainpelto. Leiden: Brill Nijhoff, vol. 1, ISBN 978-90-04-29742-5.

Defeis, Elizabeth. 2017. Human Rights, the European Union, and the Treaty Route: From Maastricht to Lisbon. Fodham International Law Journal 35: 1207-30.

Di Federico, Giacomo, ed. 2011. The EU Charter of Fundamental Rights: From Declaration to Binding Instrument. Dordrecht: Springer, ISBN 9789400701557.

Di Stefano, Manlio. 2016. Harmonising the Protection of Unaccompanied Minors in Europe. Report Doc. 14142. Strasbourg: Committee on Migration, Refugees and Displaced Persons.

Douglas-Scott, Sionaidh. 2011. The European Union and Human Rights after the Treaty of Lisbon. Human Rights Law Review 11: 645. [CrossRef]

European Council on Refugees and Exiles (ECRE). 2014. Quality Legal Assistance for Unaccompanied Children-Comparative Report. Strasbourg: European Council on Refugees and Exiles.

European Council on Refugees and Exiles (ECRE). 2017. ECRE/ELENA Call on European States to Ensure That Legal Aid Is Provided to All Asylum Applicants without Sufficient Means, at All Stages of the Asylum Procedure and Regardless of the Specific Asylum Procedures That They May Fall under. Strasbourg: European Council on Refugees and Exiles.

EUROSTAT. 2021. Number of First-Time Asylum Applicants Aged Less than 18 Years Old in the EU, 2010-2020. Luxembourg: EUROSTAT.

Fontanelli, Filippo. 2014. National Measures and the Application of the EU Charter of Fundamental Rights-Does curia.eu Know iura.eu? Human Rights Law Review 14: 231-65. [CrossRef] 
European Union Agency for Fundamental Rights (FRA). 2014. Guardianship for Children Deprived of Parental Care. Vienna: European Union Agency for Fundamental Rights.

European Union Agency for Fundamental Rights (FRA). 2018. Migration to the EU: Five Persistent Challenges. Vienna: European Union Agency for Fundamental Rights.

Garlick, Madeline. 2015. International Protection in Court: The Asylum Jurisprudence of the Court of Justice of the EU and UNHCR. Refugee Survey Quarterly 34: 107-30. [CrossRef]

Guild, Elspeth. 2015. The Asylum Seekers' Right to Free Legal Assistance and/or Representation in EU law. In Issues in International Migration Law. Edited by Plender Richard. Leiden: Koninklijke Brill, pp. 261-84. ISBN 978-90-04-20851-3.

Hancox, Emily. 2013. The meaning of “implementing" EU law under Article 51(1) of the Charter: Åkerberg Fransson. Common Market Law Review 50: 1411-31.

Ippolito, Francesca, and Sara Sanchez Iglesias. 2015. Protecting Vulnerable Groups: The European Human Rights Framework. London: Hart Publishing, ISBN 9781849466851.

Kilkelly, Ursula. 1999. The Child and the European Convention on Human Rights. Aldershot: Ashgate, ISBN 1840147040.

King, Shani. 2013. Alone and Unrepresented: A call to congress to provide counsel for unaccompanied minors. Harvard Journal on Legislation 50: 331.

Liefaard, Ton. 2019. Access to Justice for Children: Towards a Specific Research and Implementation Agenda. International Journal of Children's Rights 27: 195-227. [CrossRef]

Smyth, Ciara. 2018. The jurisprudence of the European Court of Human Rights relevant to child migrants. In Research Handbook on Child Migration. Edited by Jacqueline Bhabha, Jyothi Kanics and Daniel Senovilla Hernández. Cheltenham: Edward Elgar Publishing Limited, ISBN 9781786433695.

UN High Commissioner for Refugees (UNHCR). 1997. Guidelines on Policies and Procedures in Dealing with Unaccompanied Children Seeking Asylum. Geneva: UNHCR.

UN High Commissioner for Refugees (UNHCR). 2009. Guidelines on International Protection: Child Asylum Claims under Articles 1(A) 2 and 1(F) of the 1951 Convention and/or 1967 Protocol Relating to the Status of Refugees. Geneva: UNHCR.

UN High Commissioner for Refugees (UNHCR). 2019. Desperate Journeys, Refugee and Migrant Children Arriving in Europe and How to Strengthen Their Protection. Geneva: UNHCR. 